\title{
Self-selected unrefined and refined carbohydrate diets do not affect metabolic control in pump-treated diabetic patients
}

\author{
A. Venhaus and E. Chantelau \\ Medical Department of Nutrition and Metabolic Diseases, WHO Collaborating Center for Diabetes Prevention and Treatment, \\ Düsseldorf University, FRG
}

\begin{abstract}
Summary. This study investigated whether unrefined or refined carbohydrate diets have any effect on metabolic control and on insulin requirement in near-normoglycaemic Type 1 (insulin-dependent) diabetic out-patients on continuous subcutaneous insulin infusion therapy. Two females and 8 males (aged $27 \pm 9$ years; diabetes duration $13 \pm 8$ years; duration of insulin pump therapy $22 \pm 5$ months; means \pm SD) participated in a randomised cross-over study with two 6-week periods on self-selected refined and unrefined carbohydrate diets respectively. As a result, energy intake differed between the experimental diets $(2372 \pm 669 \mathrm{kcal} /$ day on unrefined diet vs $2757 \pm 654 \mathrm{kcal} /$ day on refined diet, $p=0.04$ ), as did the fibre intake $(18 \pm 5 \mathrm{~g} /$ day with the refined carbohydrate diet vs $35 \pm 13 \mathrm{~g}$ /day with the unrefined carbohy-
\end{abstract}

drate diet, $p=0.02$ ). The composition of nutrients was approximately $40 \%$ carbohydrate, $45 \%$ fat, and $13 \%$ protein with both diets. Body weight, $\mathrm{HbA}_{1 \mathrm{c}}$, daily mean blood glucose $(7.2 \pm 0.6 \mathrm{mmol} / \mathrm{l})$ and serum lipids remained virtually unchanged during the entire study. Insulin requirement varied between $40.1 \pm 7.9 \mathrm{U} /$ day with the unrefined carbohydrate diet, and $42.5 \pm 10.1 \mathrm{U} /$ day with the refined carbohydrate diet (NS). Thus, neither the refined nor the unrefined carbohydrate diet affected insulin requirement and metabolic control in these near-normoglycaemic, normolipaemic, nonobese, insulin-pump-treated Type 1 diabetic patients.

Key words: Unrefined diet, Type 1 (insulin-dependent) diabetes, intensive insulin therapy.
Unrefined carbohydrate foods, e.g. carbohydrate foods rich in naturally occuring dietary fibres, have been advocated by numerous authors in the treatment of various diseases for decades [1]. Regarding diabetes mellitus, a high-carbohydrate, high-fibre diet has been claimed to improve metabolic control at reduced insulin dosages [2-6]. Slama et al. [7] have shown that the addition of pectin to a standard breakfast was followed by a $35 \%$ reduction in insulin requirement in Type 1 (insulin-dependent) diabetic patients connected to an artificial pancreas.

However, insulin requirements during either a high-carbohydrate, high-fibre diet [8], or an average refined low-fibre Western diet [9], have also been observed as unchanged in Type 1 diabetic patients.

To further clarify whether the refinement of carbohydrate foods has an impact on insulin requirement we have performed a randomised cross-over study with self-selected unrefined and refined carbohydrate diets in well-controlled, non-obese Type 1 diabetic out-patients on continuous subcutaneous insulin infusion (CSII) therapy.

\section{Subjects and methods}

\section{Subjects}

Ten Type 1 diabetic patients ( 2 females, 8 males; aged $27 \pm 9$ years; diabetes duration $13 \pm 8$ years; duration of insulin pump therapy $22 \pm 5$ months; means $\pm S D$ ) volunteered to participate in the study. The study was carried out in accordance with the Helsinki Declaration [10]. All patients were C-peptide negative (post-absorptive Cpeptide levels $<0.3 \mathrm{ng} / \mathrm{ml}$ ) and non-obese (body mass index $22.6 \pm$ $1.7 \mathrm{~kg} / \mathrm{m}^{2}$ ). The patients had been on CSII and a liberalised diet [11] for more than 1 year. Their daily insulin dose was approximately $0.6 \mathrm{U} / \mathrm{kg}$ body weight. At the beginning of the study, the patients were well-controlled, as indicated by near-normal $\mathrm{HbA}_{1 \mathrm{c}}$ levels and normal serum lipids (Table 1).

\section{Study design}

After a four-week run-in period on their habitual diet, the patients were instructed to consume unrefined and refined carbohydrate diets, each of a six-week period in random order, according to Thornton et al. [12] and Kinmonth et al. [13].

During the unrefined carbohydrate diet (URD), refined fibre-depleted carbohydrates such as sucrose, white bread, white rice, mashed potatoes and other highly-processed (e.g. boiled, canned, dried. flaked) foods. including iuices. were to be avoided. excent for 
Table 1. Clinical data of the patients during habitual diet, before randomisation on experimental diets

\begin{tabular}{|c|c|}
\hline Body weight (kg) & $68.8 \pm 11.1$ \\
\hline Random plasma glucose $(\mathrm{mmol} / \mathrm{l})$ & $6.8 \pm 2.3$ \\
\hline $\mathrm{HbA}_{1 \mathrm{c}}(\%$ of total $\mathrm{Hb})$ & $6.4 \pm 0.7$ \\
\hline Triglycerides $(\mathrm{mmol} / \mathrm{l})$ & $1.63 \pm 1.04$ \\
\hline Total cholesterol $(\mathrm{mmol} / \mathrm{l})$ & $4.81 \pm 0.75$ \\
\hline HDL-cholesterol (mmol/l) & $1.56 \pm 0.39$ \\
\hline Apolipoprotein A-I (mg/dla & $170 \pm 21$ \\
\hline Apolipoprotein B (mg/dl) & \pm 21 \\
\hline Energy intake (kcal/day) & \pm 658 \\
\hline Carbohydrate intake (g/day) & \pm 64 \\
\hline $\begin{array}{l}\text { Intake of simple sugars with fructose included } \\
(\mathrm{g} / \text { day })\end{array}$ & \pm 41 \\
\hline Intake of complex carbohydrates (g/day) & \pm 33 \\
\hline Fat intake ( $\mathrm{g}$ /day) & \pm 40 \\
\hline Protein intake (g/day) & $97 \pm 29$ \\
\hline $\begin{array}{l}\text { Daily insulin dosage (U/day) prandial insulin } \\
\text { dose }\end{array}$ & $20.9 \pm 4.8$ \\
\hline Total dose & $41.7 \pm 6.9$ \\
\hline
\end{tabular}

${ }^{a}$ Apolipoproteins are given in $\mathrm{mg} / \mathrm{dl}$ since the molar weight of these compounds is still uncertain

Table 2. Dietary assessment

\begin{tabular}{|c|c|c|c|}
\hline & URD & $\mathrm{RD}$ & $p$-value \\
\hline $\begin{array}{l}\text { Fibre intake (g/day) } \\
\qquad(\mathrm{g} / 1000 \mathrm{kcal})\end{array}$ & $\begin{array}{r}35.5 \pm 13.0 \\
14.9 \pm 2.8\end{array}$ & $\begin{aligned} 17.9 \pm & 5.1 \\
6.5 \pm & 1.9\end{aligned}$ & $\begin{array}{l}p=0.007 \\
p=0.005\end{array}$ \\
\hline $\begin{array}{l}\text { Energy intake } \\
\text { (kcal/day) }\end{array}$ & $2372 \pm 669$ & $2757 \pm 654$ & $p=0.04$ \\
\hline $\begin{array}{l}\text { Carbohydrate intake } \\
\text { (g/day) }\end{array}$ & $211 \pm 62$ & $249 \pm 59$ & $p=0.007$ \\
\hline $\begin{array}{l}\text { (\% of energy } \\
\text { intake) }\end{array}$ & $40 \pm 5$ & $41 \pm 4$ & NS \\
\hline $\begin{array}{l}\text { Intake of simple } \\
\text { sugars with } \\
\text { fructose included } \\
(\mathrm{g} / \text { day })\end{array}$ & $69 \pm 24$ & $96 \pm 45$ & $p=0.02$ \\
\hline $\begin{array}{l}\text { Intake of complex } \\
\text { carbohydrates } \\
\text { (g/day) }\end{array}$ & $142 \pm 48$ & $152 \pm 41$ & NS \\
\hline $\begin{array}{l}\text { Fat intake ( } g / \text { day) } \\
\text { ( } \% \text { of energy } \\
\text { intake) }\end{array}$ & $\begin{array}{r}118 \pm 39 \\
45 \pm 5\end{array}$ & $\begin{array}{r}137 \pm 35 \\
46 \pm 2\end{array}$ & $\begin{array}{l}\text { NS } \\
\text { NS }\end{array}$ \\
\hline $\begin{array}{l}\text { Protein intake } \\
\text { (g/day) }\end{array}$ & $86 \pm 29$ & $92 \pm 23$ & NS \\
\hline $\begin{array}{l}\text { (\% of energy } \\
\text { intake) }\end{array}$ & $13 \pm 2$ & $12 \pm 2$ & NS \\
\hline
\end{tabular}

$\mathrm{URD}=$ unrefined carbohydrate diet $\mathrm{RD}=$ refined carbohydrate diet

treatment of hypoglycaemia. Whole grain products, leguminous seeds such as peas, lentils and beans, and fruits and vegetables were to be chosen. The patients were instructed not to eat additional dietary fibre in the form of guar or wheat bran.

On the refined carbohydrate diet (RD), whole grain products were to be avoided, and the intake of vegetables and fruits was limited to one serving of processed vegetables per day and less than five servings of fresh fruit per week [12]. Refined sugar was permitted up to $50 \mathrm{~g} / \mathrm{day}$. Thus, with the URD the carbohydrate food had a low glycaemic index and was fibre-rich, and with the RD it had a high glycaemic index [14] and was fibre-depleted.
As the experimental diets were not provided by the investigators, but were to be selected by the patients themselves, teaching sessions were held initially for each study period to give patients theoretical and practical advice for the preparation of meals.

CSII therapy was conducted as described previously, with the basal insulin infusion rate adjusted predominantly to the fasting blood glucose level, and prandial insulin dosage adjusted according to the type and amount of carbohydrate to be ingested, with corrections made for the actual premeal blood glucose level [11, 15], and exercise. The patients were able to assess carbohydrate quantities with less than $10 \%$ deviation (unpublished data).

Patients were advised that adjustment of prandial insulin dosage with the experimental diets might be necessary, in that less prandial insulin might be required with the URD, and more prandial insulin with the RD.

\section{Dietary assessment}

Dietary intake was assessed during the last 7 days of the run-in period and the URD and RD periods using a standardised food-recording check-list system ("My personal dietary diary") developed by Pudel et al. [16]. This food record contains 152 commonly eaten foods described in household measures, such as "one half slice of white bread" or "one cup of cooked brown rice"; it was to be filled in during meal intake. The diet records were evaluated with computer assistance on the basis of standard West German food tables [17]; fibre intake was calculated according to McCane/Widdowson tables [18]. The food record system had been validated in a previous study [19], and consequently been found suitable for the purposes of this study. To further ensure proper adherence of the patients to the experimental diets, stool frequency, consistency, and quantity was monitored using a questionnaire.

\section{Assessment of metabolic control}

Self-monitoring data of blood glucose and insulin dosages were obtained from the last 4 weeks of each observation period as recorded in the patients' diabetes log books [11]. All patients were followed up in our out-patient diabetes clinic bi-weekly for determination of blood pressure, body weight (in street clothes), random non-fasting plasma glucose (Beckman Glucose Analyzer, Fullerton, Calif, USA), non-fasting serum concentrations of total cholesterol, HDL-cholesterol, apolipoproteins $\mathrm{A}-\mathrm{I}$ and $\mathrm{B}$, triglycerides and $\mathrm{HbA}_{1 \mathrm{c}}$-levels. Lipids and lipoproteins were measured using standard laboratory methods, including nephelometry for the determination of lipoproteins [20]. $\mathrm{HbA}_{1 \mathrm{c}}$ was determined with the TBA-method [21], with the normal range of our laboratory being $4.2-5.6 \%$ of total haemoglobin.

\section{Statistical analysis}

Statistical processing of the data was carried out using the SPSS programme [22]. Data are given as means $\pm \mathrm{SD}$; a $p$ value of $<0.05$ was considered statistically significant. Wilcoxon tests for matched pairs were applied, as well as analysis of variance.

\section{Results}

The results of the dietary assessment during the last seven days of the two experimental diets are shown in detail in Table 2. The patients chose to lower their energy intake during the unrefined diet (URD: $2372 \pm$ $669 \mathrm{kcal} /$ day) as compared to the refined carbohydrate diet (RD: $2757 \pm 654 \mathrm{kcal} /$ day), and varied their carbohydrate intake accordingly $(211 \pm 62 \mathrm{~g} /$ day with URD vs $249 \pm 59 \mathrm{~g} /$ day with $\mathrm{RD}, p=0.007$ ). Despite this 
Table 3. Clinical parameters of the patients, as obtained with the experimental diets under non-fasting conditions

\begin{tabular}{|c|c|c|c|c|c|c|}
\hline & \multicolumn{3}{|c|}{ Unrefined carbohydrate diet } & \multicolumn{3}{|c|}{ Refined carbohydrate diet } \\
\hline Body weight $(\mathrm{kg})$ & $69.5 \pm 11.1$ & $69.8 \pm 11.5$ & $69.0 \pm 11.2$ & $69.1 \pm 11.0$ & $70.2 \pm 11.5$ & $70.2 \pm 12.3$ \\
\hline $\mathrm{HbA}_{1 \mathrm{c}}(\%$ of total $\mathrm{Hb})$ & $5.9 \pm 0.8$ & $5.9 \pm 1.0$ & $6.3 \pm 0.8$ & $5.9 \pm 0.5$ & $6.0 \pm 0.7$ & $5.8 \pm 0.5$ \\
\hline Triglycerides $(\mathrm{mmol} / \mathrm{l})$ & $1.37 \pm 0.93$ & $1.30 \pm 0.86$ & $1.24 \pm 0.57$ & $1.48 \pm 1.33$ & $1.23 \pm 0.80$ & $1.67 \pm 1.22$ \\
\hline Total cholesterol (mmol) & $4.86 \pm 0.83$ & $4.84 \pm 0.75$ & $4.68 \pm 0.62$ & $4.76 \pm 0.78$ & $4.84 \pm 0.81$ & $4.94 \pm 0.81$ \\
\hline Apolipoprotein B (mg/dl) & $97 \pm 22$ & \pm 18 & \pm 18 & $94 \pm 27$ & \pm 24 & $97 \pm 25$ \\
\hline
\end{tabular}

Table 4. Metabolic self-monitoring

\begin{tabular}{llll}
\hline & URD & RD & $p$-value \\
\hline $\begin{array}{l}\text { Frequency of blood-glucose } \\
\text { self-monitoring/day }\end{array}$ & $4.7 \pm 1.1$ & $4.6 \pm 1.1$ & NS \\
$\begin{array}{l}\text { Mean daily blood-glucose } \\
\text { (mmol/1) }\end{array}$ & $7.3 \pm 0.8$ & $7.2 \pm 0.5$ & NS \\
$\begin{array}{l}\text { Frequency of blood-glucose } \\
\quad \text { readings } \leq 2.5 \text { mmol/1 or } \\
\text { symptomatic hypoglycaemia/ } \\
\text { month }\end{array}$ & $9.6 \pm 6.6$ & $11.4 \pm 8.5$ & NS \\
$\begin{array}{l}\text { Frequency of blood-glucose } \\
\text { readings } \geq 11 \text { mmol/1 per } \\
\text { month }\end{array}$ & $18.2 \pm 9.5$ & $16.7 \pm 7.5$ & NS \\
\hline
\end{tabular}

$\mathrm{URD}=$ unrefined carbohydrate diet; $\mathrm{RD}=$ refined carbohydrate diet

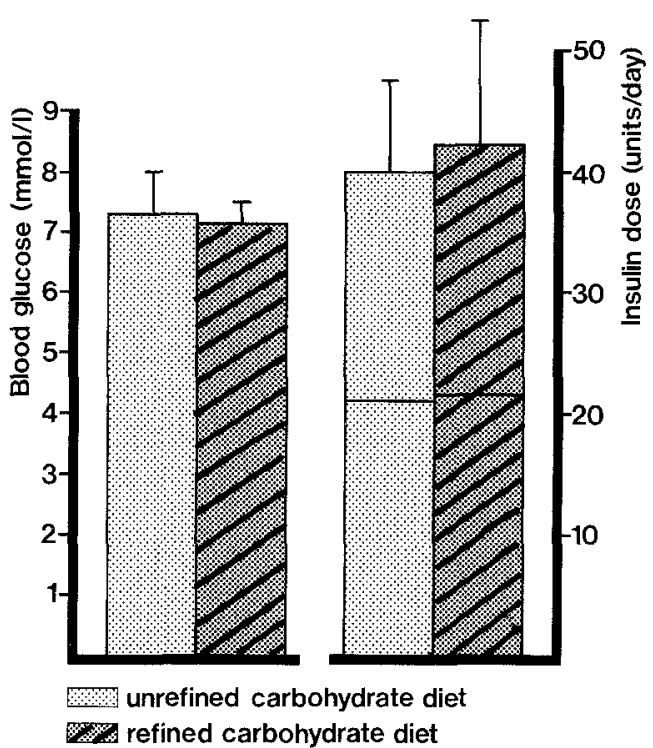

Fig. 1. Daily mean \pm SD glycaemia (left side of the diagramme) based upon self-monitoring, and daily mean \pm SD insulin supply (right side of the diagramme) as recorded by the ten patients. Horizontal bars divide the total daily insulin dose into basal rate (lower parts) and meal-related (upper parts) insulin supply

slightly lower carbohydrate intake, fibre intake was nearly $100 \%$ more with URD than with the refined carbohydrate diet $(35.3 \pm 13.0 \mathrm{~g} /$ day vs $17.9 \pm 5.1 \mathrm{~g} /$ day; $p=0.007)$. During URD, significantly fewer $(p=0.02)$ simple sugars were consumed than during RD (Table 2).

Stool frequency was increased to $1.9 \pm 0.6$ times per day with URD, as compared to $1.0 \pm 0.6$ times per day with $\mathrm{RD}(p=0.01)$. The stools appeared to be looser and more voluminous with URD.

The clinical parameters of the patients are shown in Tables 1 and 3. Upon entering the study (Table 1), all patients had normal body weight and were in good metabolic control, as indicated by near-normal $\mathrm{HbA}_{1 \mathrm{c}}$ values. Serum lipids and lipoproteins did not show any abnormality; daily insulin requirement was comparable to results reported elsewhere [11]. During the experimental periods (Table 3 ) there were no significant changes in body weight, blood pressure, $\mathrm{HbA}_{1}$, serum lipids and lipoproteins, and random non-fasting plasma glucose. There was a tendency to gain weight during the refined carbohydrate period, but this was statistically insignificant. Body mass index varied between $22.4 \pm 1.8 \mathrm{~kg} / \mathrm{m}^{2}$ and $23.0 \pm 2.1 \mathrm{~kg} / \mathrm{m}^{2}$, without changing significantly throughout the entire study. Blood pressure remained stable with systolic pressure ranging from $119 \pm 8 \mathrm{~mm} \mathrm{Hg}$ to $128 \pm 15 \mathrm{~mm} \mathrm{Hg}$, and diastolic pressure ranging from $73 \pm 10 \mathrm{~mm} \mathrm{Hg}$ to $81 \pm 5 \mathrm{~mm} \mathrm{Hg}$ (NS).

The results of the patients' metabolic self-monitoring are given in Table 4. During the two experimental periods, the number of blood glucose readings per day did not change significantly. There were $11.4 \pm 8.5$ mild hypoglycaemic episodes (i.e. blood glucose readings $\leq$ $2.5 \mathrm{mmol} / 1$, or hypoglycaemic symptoms) per month during the RD period as compared to $9.6 \pm 6.6$ per month with URD (NS). No severe hypoglycaemia with unconsciousness occurred during the entire study.

On the other hand, $16.7 \pm 7.5$ hyperglycaemic episodes (i.e. blood glucose readings $\geq 11 \mathrm{mmol} / \mathrm{l}$ ) per month were documented with RD, and $18.2 \pm 9.5$ per month during URD (NS). No ketoacidosis occurred during the entire study.

The mean daily blood glucose levels as computed from $138 \pm 33$ to $144 \pm 42$ home blood glucose readings per month were $7.3 \pm 0.8 \mathrm{mmol} / 1$ with URD, and $7.2 \pm 0.5 \mathrm{mmol} / 1$ with RD (NS; Fig. 1 ). The study had a power of $90 \%$ to detect a significant $0.3 \mathrm{mmol} / 1$ difference between the mean daily blood glucose levels. 
The mean daily insulin dosages were also computed from the patients' records (Fig. 1). With URD, the prandial insulin dose was $19.2 \pm 4.4 \mathrm{U} /$ day, and the total insulin dose was $40.1 \pm 7.9 \mathrm{U} /$ day. With $\mathrm{RD}$, the prandial insulin dose was $21.3 \pm 5.3 \mathrm{U} /$ day, and the total insulin dosage amounted to $42.5 \pm 10.1 \mathrm{U} /$ day. The differences between URD and RD were statistically insignificant ( $p>0.10$ ANOVA). The study had a power of $90 \%$ to detect a significant 2.5 -unit difference between the mean daily insulin dosages.

\section{Discussion}

The results indicate that doubling the habitual intake of dietary fibres per $1000 \mathrm{kcal}$ by increasing the intake of unrefined carbohydrates does not affect metabolic control in well-controlled Type 1 diabetic patients on CSII. Furthermore, we did not observe any significant changes in insulin dosages in relation to the unrefined and refined carbohydrate diets, although carbohydrate foods with low glycaemic index (like those used with the unrefined carbohydrate diet) have repeatedly been proven to reduce the insulinaemic response as compared to high glycaemic index carbohydrates $[9,14,15$, 23, 24, 29].

There are several explanations for these findings: firstly, the patients in our study increased their fibre intake to a maximum of approximately $35 \mathrm{~g} /$ day (Table 2) which approaches the recent recommendations of the American Diabetes Association (ADA) of $40 \mathrm{~g} /$ day [25]; however, this fibre intake is far below the $60 \mathrm{~g} /$ day in those study patients whose insulin dosage could be reduced during high-carbohydrate, highfibre diets $[2,26]$. In addition, the current carbohydrate intake in our study was lower than recommended by the ADA [25].

Secondly, our patients preferred cereal fibres known to exert less influence on glucose metabolism as compared to viscous fibres such as pectin or leguminous fibres [25]. Thirdly, our patients were all C-peptide negative and non-obese, whereas patients in whom insulin dosages could be reduced during high-fibre intake included Type 2 (non-insulin-dependent) diabetic patients transiently under insulin therapy [26]. Further, our study was performed during the winter and spring $1986 / 87$, and the patients consumed only about two servings of fresh fruits per day. Hence, the contribution of this particular type of unrefined carbohydrate to the URD was negligible, and the insulin-saving effects of a high fruit diet $[15,23,24]$ were not evident during this study. Finally, the relatively low percentage of carbohydrate in the URD, reflecting a relatively low intake of carbohydrates with a low glycaemic index and low insulin requirement like fruits (as mentioned above), leguminous seeds [27, 28] and soaked whole grain cereals [29], might as well have influenced the present results. Taking together all these arguments, it seems that the impact of the unrefined carbohydrate diet on the patients' insulin dosages in our study was too weak as compared with other effects requiring insulin dosage-adaptation, like the amount of carbohydrate, the time of day, and hypo- and hyperglycaemia [15].

Doubled fibre intake and increased stool frequency during URD as compared to RD document the patients' satisfactory compliance with both of the diets, although the refined carbohydrate diet was more easily accessible. Patients generally liked the unrefined carbohydrate diet; 4 patients stated that they would continue the URD after finishing the study. We attribute this to the patients' experiencing the overall benefits of an unrefined carbohydrate diet, e.g. the immediate feeling of satiety and presumably the looser stool.

It is of note that during the URD recording period the patients reported reduced energy intake as compared to the refined carbohydrate diet, possibly related to the bulkiness of the unrefined carbohydrate diet; comparable observations have been made in human [30] and animal [31] studies. Hence, carbohydrate intake was lowered by about $16 \%$ during the URD recording period, due largely to the avoidance of refined sugars $[11,30]$. However, prandial insulin dosages were only insignificantly lower $(19.2 \pm 4.4 \mathrm{U} /$ day) during URD as compared to RD $(21.3 \pm 5.3 \mathrm{U} /$ day $)$. This indicates once again that the prandial insulin dosages were adjusted not exclusively to the diet, but also to other factors like the premeal blood glucose reading, the time of day [15], and exercise [32]. Body weight, serum lipids, and lipoproteins varied only insignificantly in relation to the diets, remaining within the normal range throughout the entire study.

In summary, our study demonstrates that the degree of refinement of dietary carbohydrates - within practical limits [33] - has little or no impact on metabolic control and insulin therapy in near-normoglycaemic Type 1 diabetic out-patients on CSII. This does not preclude, however, that fibre-rich unrefined carbohydrate foods with low glycaemic index may attenuate postmeal glycaemic excursions in Type 1 diabetic patients on traditional therapy without meal-related boluses of regular insulin [13]. This potential benefit of an unrefined diet, however, is negligible diabetic control is poor due to insufficient insulin replacement [34, 35]. On the other hand, if intensive insulin therapy is employed, the potential insulin saving effect of such a diet may be overruled by other impacts requiring insulin dosage adaptation during Type 1 diabetes treatment.

Acknowledgements. The financial support from the Peter Klöckner Stiftung, Duisburg (FRG) and from the West German Sugar Bureau, Bonn (FRG), grants to Prof. M. Berger, is gratefully acknowledged. The authors thank Prof. M. Berger for his helpful criticism, and Ms. M. Kroll, Seattle (USA) for her excellent editorial assistance. 


\section{References}

1. Trowell H, Burkitt D, Heaton K (eds) (1985) Dietary Fibre, Fibre-Depleted Foods and Disease. Academic Press, London

2. Anderson JW, Ward K (1978) Long-Term effects of high-carbohydrate, high-fiber diets on glucose and lipid metabolism: a preliminary report on patients with diabetes. Diabetes Care 1:77-82

3. Anderson JW, Ward K (1979) High-carbohydrate, high-fiber diets for insulin-treated men with diabetes mellitus. Am J Clin Nutr 32: $2312-2321$

4. Rivellese A, Riccardi G, Giacco A, Pacioni D, Genovese S, Mattioli PL, Mancini M (1980) Effect of dietary fibre on glucose control and serum lipoproteins in diabetic patients. Lancet II: 447-450

5. Harold MR, Reeves RD, Bolze S, Guthrie RA, Guthrie DW (1985) Effect of dietary fiber in insulin-dependent diabetics: insulin requirements and serum lipids. J Am Diet Assoc 85: 1455-1461

6. Ney D, Hollingsworth DR, Cousins L (1982) Decreased insulin requirement and improved control of diabetes in pregnant women given a high-carbohydrate, high-fiber, low-fat diet. Diabetes Care 5: 529-533

7. Slama G, Klein JC, Tchobroutsky G (1983) The artificial pancreas: a tool for pharmacological studies in type-I diabetes. In: Brunetti P (ed) Artificial Systems for Insulin Delivery. Raven Press New York, pp 567-572

8. Hollenbeck CB, Riddle MC, Connor WE, Leklem JE (1985) The effects of subject-selected high carbohydrate, low-fat diets on glycemic control in insulin-dependent diabetes mellitus. Am J Clin Nutr 41: 293-298

9. Krarup-Hansen A, Lauritzen T, Sandahl-Christiansen J, AabySvendsen P, Deckert T (1982) Diet versus average Danish food in insulin-dependent diabetes mellitus. Scand Lab Clin Invest 42: 603-606

10. Editorial (1978) The policy of the European Association for the Study of Diabetes on human investigation. Diabetologia 15: $431-432$

11. Chantelau E, Gösseringer G, Sonnenberg GE, Berger M (1985) Moderate intake of sucrose does not impair metabolic control in pump-treated diabetic out-patients. Diabetologia 28: 204-207

12. Thornton JR, Emmett PM, Heaton KW (1983) Diet and gall stones: effects of refined and unrefined carbohydrate diets on bile cholesterol saturation and bile acid metabolism. Gut 24:2-6

13. Kinmonth AL, Angus RM, Jenkins PA, Smith MA, Baum JD (1982) Whole foods and increased dietary fibre improve blood glucose control in diabetic children. Arch Dis Child 57: 187-194

14. Jenkins DJA, Jenkins AL, Wolevèr TMS, Josse RG, Wong GS (1984) The glycaemic response to carbohydrate foods. Lancet II: 388-391

15. Chantelau E, Spraul M, Kunze K, Sonnenberg GE, Berger M (1986) Effects of the glycaemic index of dietary carbohydrates on prandial glycaemia and insulin therapy in type-I diabetes mellitus. Diabetes Res Clin Pract 2: 35-41

16. Pudel V, Schlaf G, Tischner G, Jansen J (1982) Läßt sich individuelle Ernährungsinformation standardisieren? Ernährungs-Umschau 29:390-395

17. Souci SW, Fachmann W, Kraut H (1986) Die Zusammensetzung der Lebensmittel. Nährwert-Tabellen 1986/87, Dritte Auflage. Wissenschaftliche Verlagsgesellschaft Stuttgart

18. Paul AA, Southgate DAT (eds). McCance and Widdowson's the composition of foods. London HMSO (1978)

19. Venhaus A (1988) Letter to the Editor. Am J Clin Nutr 47: 162-163

20. Rosseneu M, Vercaemst R, Vinaiment N, Van Tornout P, Hen- derson LO, Herbert PN (1981) Quantitative determination of human plasma apolipoprotein A-I by laser immun-nephelometry. Clin Chem 27: 865-70

21. National Diabetes Data Group (1984) Report of the expert committee on glucosylated hemoglobin. Diabetes Care 7: 602-606

22. Nie NH, Hull CH, Jenkins JG, Steinbrenner K, Bent D (1975) SPSS, Statistical Package for the Social Sciences. McGraw-Hill, New York

23. Gannon MC, Nuttall FQ, Krezowski PA, Billington CJ, Parker S (1986) The serum insulin and plasma glucose responses to milk and fruit products in Type 2 (non-insulin-dependent) diabetic patients. Diabetologia 29:784-791

24. Haber GB, Heaton KW, Murphy D, Burroughs LF (1977) Depletion and disruption of dietary fibre; effects on satiety, plasmaglucose, and serum-insulin. Lancet II: 679-682

25. American Diabetes Association (1987) Nutritional recommendations and principles for individuals with diabetes mellitus: 1986. Diabetes Care 10: 126-132

26. Mann JI (1985) Diabetes mellitus: some aspects of aetiology and management of non-insulin-dependent diabetes. In: Trowell $\mathrm{H}$, Burkitt D, Heaton KW (eds) Dietary Fibre, Fibre-Depleted Foods, and Diseases. Academic Press, London, pp 263-288

27. Tappy L, Würsch P, Randin JP, Felber JP, Jequier E (1986) Metabolic effect of pre-cooked instant preparations of bean and potato in normal and in diabetic subjects. Am J Clin Nutr 43: 30-36

28. Kronsbein P, Kempf U, Chantelau E, Berger M (1987) Insulin* bedarf von Linsenmahlzeiten bei Insulinpumpen-behandelten Typ-I Diabetikern (Abstract). Ernährungs-Umschau 34: 92

29. Sichert-Oevermann W, v Koerber K, Bretthauer B, Leitzmann C, Laube $H$ (1987) Blutglucose- und Insulinverlauf bei Gesunden und Diabetikern nach Gabe roher Vollkornzubereitungen, insbesondere Frischkornmüsli. Dtsch Med Wochenschr 112: $1977-1983$

30. Stevens J, Levitsky DA, Van Soest PJ, Robertson JB, Kalkwarf HJ, Roe DA (1987) Effect of psyllium gum and wheat bran on spontaneous energy intake. Am J Clin Nutr 46: 812-817

31. Nygren C, Hallmanns G, Lithner F (1981) Long term effects of dietary fibre in bread on weight, blood glucose, glucosuria and fecal fat excretion in allocan diabetic tats. Diabete Metabol 7: $115-120$

32. Sane TA, Helve E, Pelkonen R, Koivisto VA (1988) Adjustment of diet and insulin dose during long-term endurance exercise in Type 1 (insulin-dependent) diabetic men. Diabetologia 31:35-40

33. Geekie MA, Porteous J, Hockaday TDR, Mann JI (1985) Acceptability of high-fibre diets in diabetic patients. Diabetic Med 3: 65-68

34. Lindsay AN, Hardy S, Jarrett L, Rallison ML (1984) High-carbohydrate, high-fiber diet in children with type-I diabetes mellitus. Diabetes Care 7: 63-67

35. Weyman-Daum M, Fort P, Recker B, Lanes R, Lifshitz F (1987) Glycemic response in children with insulin-dependent diabetes mellitus after high- or low-glycemic index breakfast. Am J Clin Nutr 46: 798-803

Received: 17 August 1987

and in revised form: 14 January 1988

Dr. E. Chantelau

Diabetesambulanz

MNR-Klinik

Universität Düsseldorf

Moorenstraße 5

D-4000 Düsseldorf

FRG 